\title{
An assessment of population fluctuations of a hemipteran citrus pest in the northeast of Algeria: A case study from Guelma region
}

\author{
Omar KHALADI ${ }^{1,2}$ and Atika GUENDOUZ-BENRIMA ${ }^{1}$
}

Received February 28, 2019; accepted June 19, 2019.

Delo je prispelo 28. februarja 2019, sprejeto 19. junija 2019.

\begin{abstract}
An assessment of population fluctuations of a hemipteran citrus pest in the northeast of Algeria: A case study from Guelma region

Abstract: In this study, which takes place in the northeast of Algeria at the region of Guelma between January 2016 and June 2017, we were able to follow the spatio-temporal evolution of the main hemipteran pests in an orchard of citrus (orange variety). This monitoring showed the presence of 12 hemipteran species, their appearance in the orchard is closely linked to the sap flow. The most abundant species was Aleurothrixus floccosus. The number of the other species that found was very small or absent in most of the time. We also noted that Aonidiella aurantii and Chrysomphalus dictyospermi had a preference to develop in the center of the tree while the other species found, which are: Dialeurodes citri, Aphis gossypii, Aphis spiraecola, Lepidosaphes beckii, Parlatoria ziziphi, Saissetia olea, Coccus hesperidum, Coccus pseudomagnoliarum and Icerya purchasi, were found in the sunniest parts of the tree.

Key words: orange; Hemiptera; Guelma; monitoring; cardinal directions
\end{abstract}

Ocena nihanja populacij škodljivcev iz reda Hemiptera na pomarančevcu v severovzhodni Alžiriji: Vzorčna študija na območju Guelma

Izvleček: V raziskavi, ki je potekala na območju Guelma, v severovzhodni Alžiriji, med januarjem 2016 in junijem 2017, je bil zasledovan prostorski in časovni razvoj glavnih škodljivcev iz reda Hemiptera v nasadu pomarančevca. Monitoring je pokazal prisotnost 12 vrst iz omenjenega reda, njihovo pojavljanje v sadovnjaku je bilo tesno povezano s tokom sokov v rastlinah. Najbolj pogosta je bila vrsta Aleurothrixus floccosus. Število ostali najdenih vrst je bilo zelo majhno ali so bile te odsotne večino časa. Opaženo je bilo tudi, da sta se vrsti Aonidiella aurantii in Chrysomphalus dictyospermi najraje razvijali v središču krošenj medtem, ko so bile ostale vrste, kot so Dialeurodes citri, Aphis gossypii, Aphis spiraecola, Lepidosaphes beckii, Parlatoria ziziphi, Saissetia olea, Coccus hesperidum, Coccus pseudomagnoliarum in Icerya purchasi, najpogosteje najdene na obrobnih, dobro osvetljenih delih krošen pomarančevca.

Ključne besede: pomarančevec; Hemiptera; Guelma; monitoring; glavne usmeritve

1 University Saad Dahlad Blidal, Faculty of Sciences of Nature and Life, Department of Biotechnology, Laboratory of Biotechnology of Plant Production, Algeria

2 Corresponding author, e-mail: omarkhbiopest@hotmail.fr 


\section{INTRODUCTION}

The pests of citrus are numerous, among them, there are mites, thrips, the Mediterranean fruit fly, the leafminer and hemipteran species (Kheder et al., 2002; Affandi et al., 2005; Szyniszewska \& Tatem, 2014; Belaam-Kort \& Boulahia-Kheder, 2017; Da-Silva et al., 2017).

Several hemipteran species are associated with citrus, the most common being whiteflies (Onillon \& Abbassi, 1973; Benmessaoud-Boukhalfa \& Chebrou, 2014), aphids (Benhalima-Kamel et al., 1994; Lebbal \& Laamari, 2016), scales (Campolo et al., 2014; Dao et al., 2017) and leafhoppers (Zina et al., 2013).

The damage of these insects on the tree is important, either directly by their sucking sap or indirectly, as a vector of virus causing viral disease, like in the case of the aphid Toxoptera citricida Kirkaly, 1907 vectoring the causing agent of tristeza (Tang et al., 1999). Therefore, the fight against these pests is important, for this, the knowledge of their population dynamics is essential for the protection of our crops (Kindlmann \& Dixon, 2010).

Although hemipteran species are dangerous pests in citrus orchards, little is known about them in the Eastern of Algeria, with the exception of a few studies such as of Lebbal and Laamari on aphids in the province of Skikda (Algeria) (Lebbal \& Laamari, 2016)

In this study, we have established an inventory of the different hemipteran species that are present in a citrus orchard in the Northeast of Algeria at the Guelma region. Through this study, we want to know the pest species richness of the study orchard and the spatio-temporal variations of the pests in this region.

\section{MATERIALS AND METHODS}

\subsection{PRESENTATION OF THE STUDY SITE}

The study was conducted in a citrus orchard ('Thomson Navel') located northwest of the province of Guelma (Algeria). It is a private farm (SARL BOUKHMIS) which occupies an area of nearly 20 hectares and is located at the entrance of the El Fedjoudj village (Guelma, Algeria).

The region is characterized by a Mediterranean climate with a semi-arid a bioclimatic stage and temperate winter. The precipitations are often observed during winter and spring.

The campaign study (January 2016 to June 2017) was characterized by a total precipitation of $674.4 \mathrm{~mm}$ (437.4 mm during the year 2016 and $237 \mathrm{~mm}$ during the six months of experimentation in 2017). The coldest month was January, with a minimum average temperature of $5.5^{\circ} \mathrm{C}$ and $4.3^{\circ} \mathrm{C}$, and an average maximum tem- perature of $18.8^{\circ} \mathrm{C}$ and $14.3^{\circ} \mathrm{C}$ during the year 2016 and 2017 respectively. The hottest months with a temperature that often exceeds $25^{\circ} \mathrm{C}$ were June, July, and August.

\subsection{SAMPLING}

The monthly monitoring of insects starts in January 2016 until June 2017, in a citrus orchard (orange variety). We delineated an area of one hectare, in which 12 trees were chosen randomly, taking five shoots with five leaves for each (i.e. 25 leaves in total) and this for each cardinal direction (two directions per tree), and also the center of the canopy. We change the directions each time we change the tree ( 8 trees for the cardinal directions, and four trees for the center). Samples brought back to the laboratory were identified using a simplified pest identification guide (Garcia-Marí, 2009)

\subsection{DATA ANALYSES}

The results obtained were subjected to statistical analysis using Past software (version 3.10). To compare the different families found, we used the Kruskal-Wallis test followed by the Mann-Whitney test pairwise comparison (with Bonferroni corrected $\mathrm{p}$ values).

The relation between the species found and their periods of appearance and also their relationship with the cardinal directions were shown by a correspondence analysis (CA), followed by a hierarchical classification by considering the coordinates on the first axes, so that at least $50 \%$ of the cumulative variance is observed.

The correlation and its significance between the percentage of infested leaves and the mean number per leaf were calculated by choosing the correlation of Spearman (rs).

\section{RESULTS}

\subsection{TAXONOMIC COMPOSITION}

A total of 5079 individuals distributed in 12 species belonging to the families of Diaspididae, Coccidae, Margarodidae, Aleyrodidae and Aphididae were recorded in the study orchard during the 18 months of sampling. The family of Diaspididae was represented by four species followed by the family of Coccidae with three species then the family of Aleyrodidae and Aphididae with two species and finally the family of Margarodidae with a single species.

In terms of abundance, the Aleyrodidae family rep- 


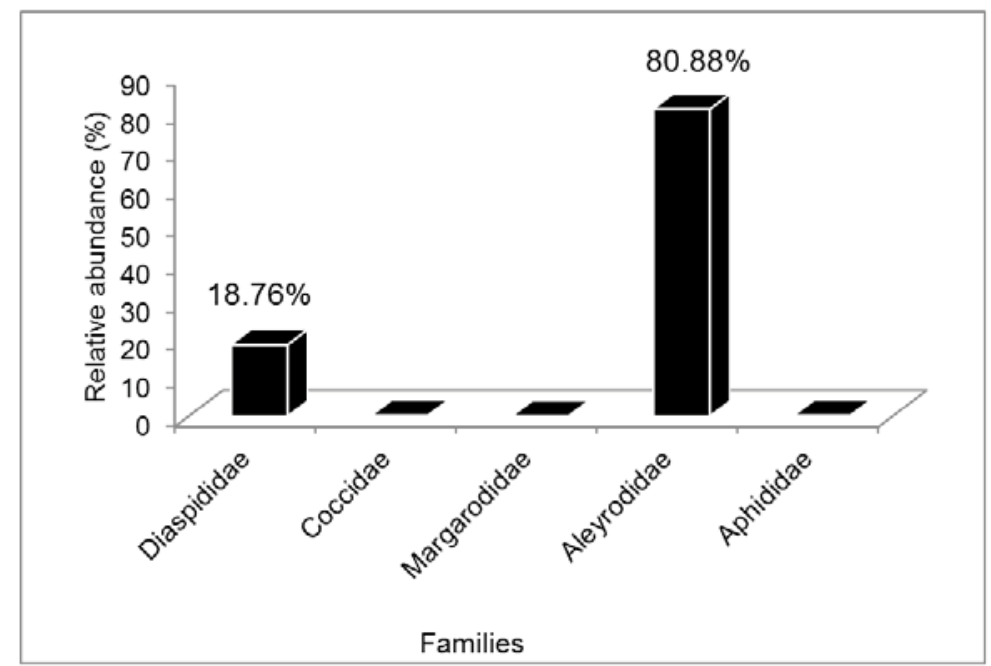

Figure 1: Relative abundances of the different families.

resented $80.88 \%$ of the total effective, followed by the family of Diaspididae with $18.76 \%$, while the other three families accounted a total of $0.36 \%$ (Figure 1).

The Kruskal-Wallis test showed a highly significant difference between families $(\mathrm{H}=66.99$ and $\mathrm{p}=0.000)$. For more details on this difference, we used the MannWhitney test pairwise comparison (Mann-Whitney with Bonferroni corrected $\mathrm{p}$ values) using PAST software (version 3.10). This test showed that there is no difference between the family of Diaspididae and Aleyrodidae with a probability "p" greater than 0.05 , whereas the difference between these two families and the others was highly significant $(p<0.000)$ (Table 1$)$.

\subsection{RELATIVE ABUNDANCE AND TEMPORAL VARIATION OF SPECIES}

The abundance results of the twelve species found during the sampling period from January 2016 to June 2017 showed that $80.49 \%$ of the total number belong to the whitefly Aleurothrixus floccosus Maskell, 1896 (larvae and eggs) followed by the California red scale Aoni- diella aurantii Maskell, 1879 with $17.46 \%$ and Chrysomphalus dictyospermi Morgan, 1889 with $1.24 \%$ of total number (Table 2).

Regarding the temporal evolution of these species, we noticed the presence of two main peaks for A. auran$t i i$, the first was during the month of March 2016 and the second during the month of January 2017, we can also notice another peak that comes to appear with the month of June 2017 (Figure 2). While the whitefly A.floccosus, an important peak was observed during the month of February 2016 and three other weakest peaks, in the months of July 2016, November 2016 and one during June 2017 (Figure 3). Two peaks also for C.dictyospermi were recorded, one during June 2016 and the other during June 2017 (Figure 2).Regarding the other species; their numbers were very small to determine their evolution's peaks.

In order to highlight the relationship between the species and their periods of appearance, the total population matrix which contains the species found in rows and the dates of exits in columns was subjected to a correspondence analysis (CA). This analysis allowed us to classify larvae of whitefly A.floccosus and the California red scale A. aurantii into the same group due to the simultaneous presence of

Table 1: Comparison between the different families with the test Mann-Whitney (Bonferroni corrected $\mathrm{p}$ values)

\begin{tabular}{llllll}
\hline & Diaspididae & Coccidae & Margarodidae & Aleyrodidae & Aphididae \\
\hline Diaspididae & - & & & \\
Coccidae & $4.20 \mathrm{E}-06^{\star * *}$ & - & & \\
Margarodidae & $8.71 \mathrm{E}-07^{\star * *}$ & $0.9246 \mathrm{NS}$ & - & & \\
Aleyrodidae & $1 \mathrm{NS}$ & $3.83 \mathrm{E}-05^{\star * *}$ & $3.92 \mathrm{E}-06^{* * *}$ & $1.23 \mathrm{E}-05^{\star * *}$ & - \\
Aphididae & $1.66 \mathrm{E}-06^{* * *}$ & $1 \mathrm{NS}$ & $1 \mathrm{NS}$ & \\
\hline
\end{tabular}

***: Significant at the $p<0.001$ level; NS: Not Significant. 
Table 2: Relative abundance of species found during the sampling period (January 2016 to June 2017)

\begin{tabular}{|c|c|c|c|c|}
\hline Order & Family & Species & $\begin{array}{l}\text { Total effective (January } 2016 \\
\text { June 2017) }\end{array}$ & $\begin{array}{l}\text { Relative abun- } \\
\text { dance }(\%)\end{array}$ \\
\hline \multirow{12}{*}{ 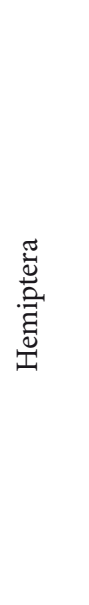 } & \multirow[t]{4}{*}{ Diaspididae } & Aonidiella aurantii (Maskell, 1879) & 887 & 17.46 \\
\hline & & Lepidosaphes beckii (Newman, 1869) & 1 & 0.02 \\
\hline & & Parlatoria ziziphi (Lucas, 1853) & 2 & 0.04 \\
\hline & & Chrysomphalus dictyospermi (Morgan, 1889) & 63 & 1.24 \\
\hline & \multirow[t]{3}{*}{ Coccidae } & Saissetia olea (Olivier, 1791) & 3 & 0.06 \\
\hline & & Coccus hesperidum (Linnaeus, 1758) & 4 & 0.08 \\
\hline & & Coccus pseudomagnoliarum (Kuwana, 1914) & 2 & 0.04 \\
\hline & Margarodidae & Icerya purchasi (Maskell, 1878) & 2 & 0.04 \\
\hline & \multirow[t]{2}{*}{ Aleyrodidae } & Aleurothrixus floccosus (Maskell, 1896) & 4088 & 80.49 \\
\hline & & Dialeurodes citri (Ashmead, 1885) & 20 & 0.39 \\
\hline & \multirow[t]{2}{*}{ Aphididae } & Aphis spiraecola (Patch, 1914) & 6 & 0.12 \\
\hline & & Aphis gossypii (Glover, 1877) & 1 & 0.02 \\
\hline
\end{tabular}

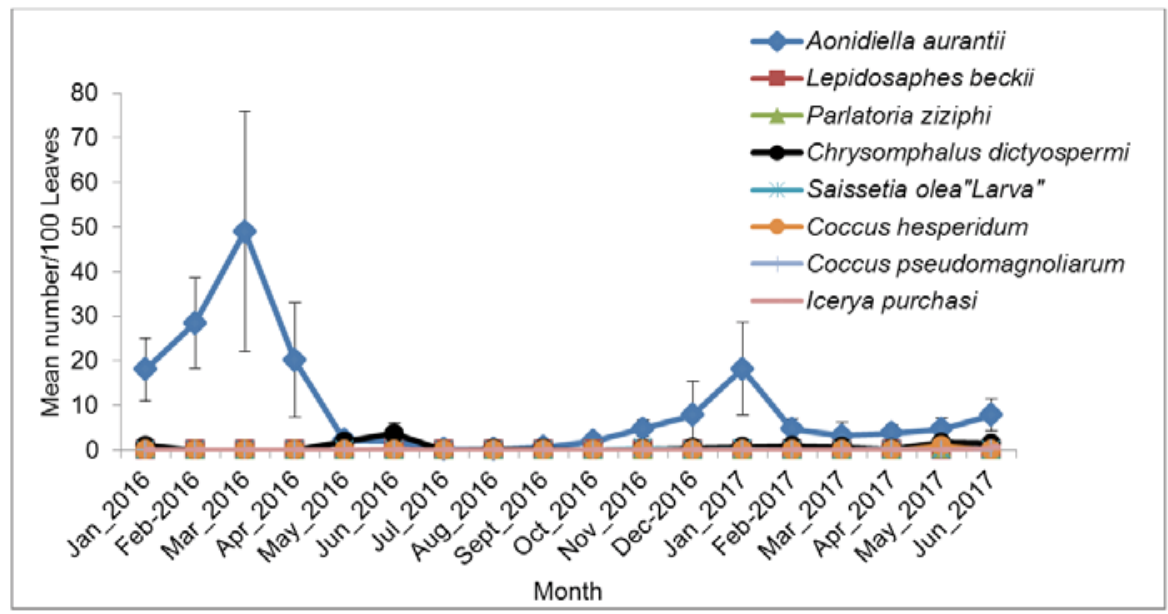

Figure 2: Annual development and population fluctuations of scales found during the sampling period (January 2016 to June 2017) (Mean \pm SE).

these two species during the entire sampling period. The two aphids Aphis spiraecola and A.gossypii were found during the month of September. Concerning the eggs of the whitefly A.floccosus, they were found mainly during the month of November with an important number compared to the other months. For the other species found, their numbers were not so important throughout the sampling period (Figure $4)$.

\subsection{SPATIAL DISTRIBUTION OF SPECIES}

In order to highlight the preference of the car- dinal directions of the trees canopy by the species found, a data matrix containing the species found in rows and the direction cardinals in columns was subjected to a correspondence analysis (CA). Taking into account the first two factorial axes which contain more than $97 \%$ of the total information with respectively $84.24 \%$ and $13.23 \%$, this analysis revealed that the two scales of Diaspididae A. aurantii and C.dictyospermi presented a preference towards the center part of the tree while the other species including the whitefly A.floccosus showed a preference towards the two sunniest parts of the canopy which are the east and south of the tree. Coccus hesperidum 


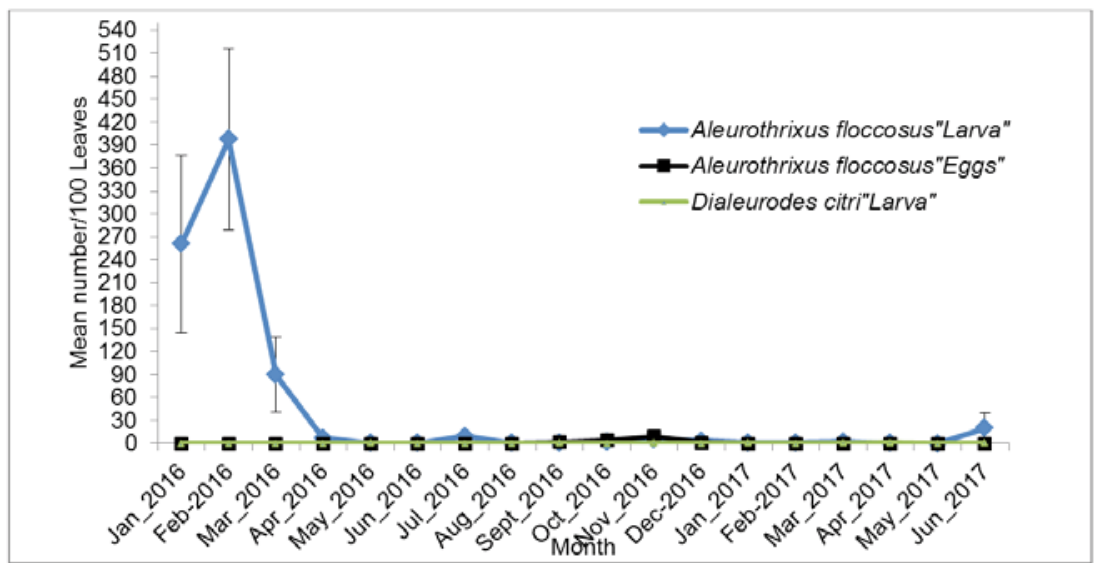

Figure 3: Annual development and population fluctuations of Whiteflies found during the sampling period (January 2016 to June 2017) (Mean \pm SE).

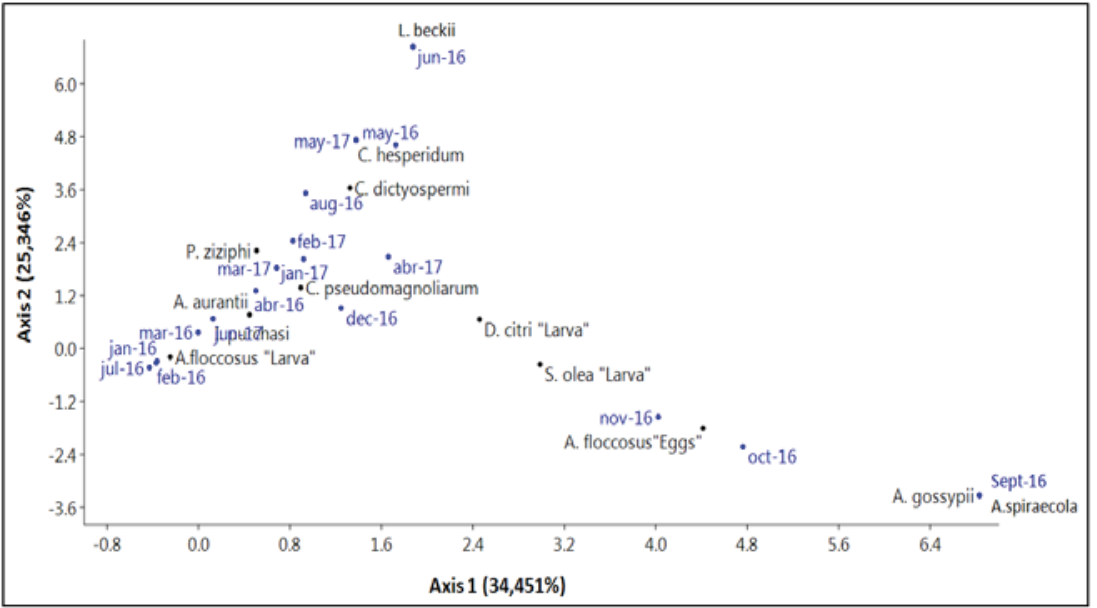

Figure 4: A correspondence analysis (CA) of species found during the sampling period (January 2016 to June 2017)

and A.gossypii were found despite their low numbers in the north direction (Figure 5).

\subsection{RELATIONSHIP BETWEEN PERCENTAGE OF OCCUPIED LEAVES AND THE MEAN NUM- BER PER LEAF}

In this part, we will focus on the most abundant species and that it concerns the California red scale and the larvae of the whitefly A.floccosus. We calculated Spearman's correlation coefficient (rs) and its significance. According to the figure 6, we note that there is a highly significant correlation between the percentage of leaves occupied by California red scale and its mean number per leaf with $\mathrm{rs}=0.98$ and $\mathrm{p}=0.000<0.001$. The same result is also obtained with the whitefly A.floccosus with a highly significant correlation ( $\mathrm{rs}=0.88, \mathrm{p}=0.000$ ) (Figure 7).

\section{DISCUSSION}

This study allowed us to establish a temporal followup of the main hemipteran pests in a citrus orchard according to the cardinal directions of the tree.

The 18-months sampling period allowed us to identify 12 species belonging to five different families. Among these species, the woolly whitefly was the most abundant followed by California red scale and then C.dictyospermi. 


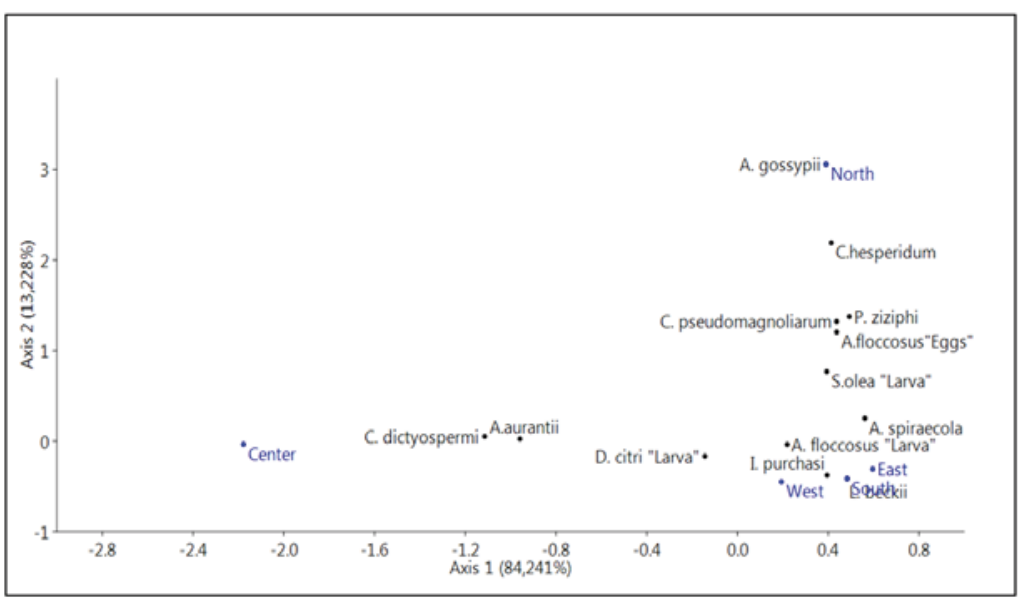

Figure 5: A correspondence analysis (CA) of the species found according to the cardinal directions of the tree

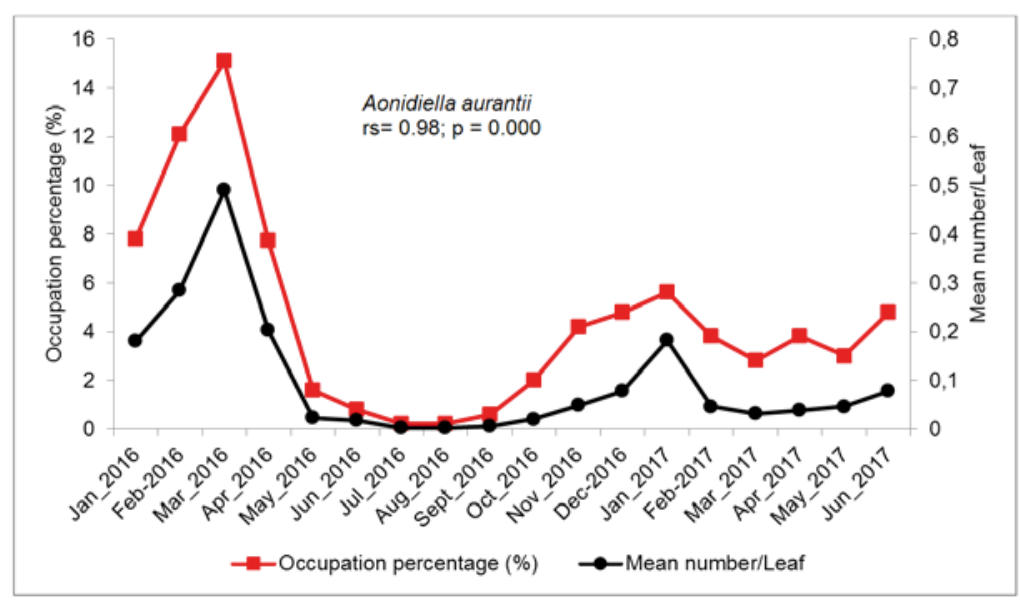

Figure 6: Temporal evolution of the mean number per leaf and the percentage of leaves occupied by Aonidiella aurantii (January 2016 to June 2017)

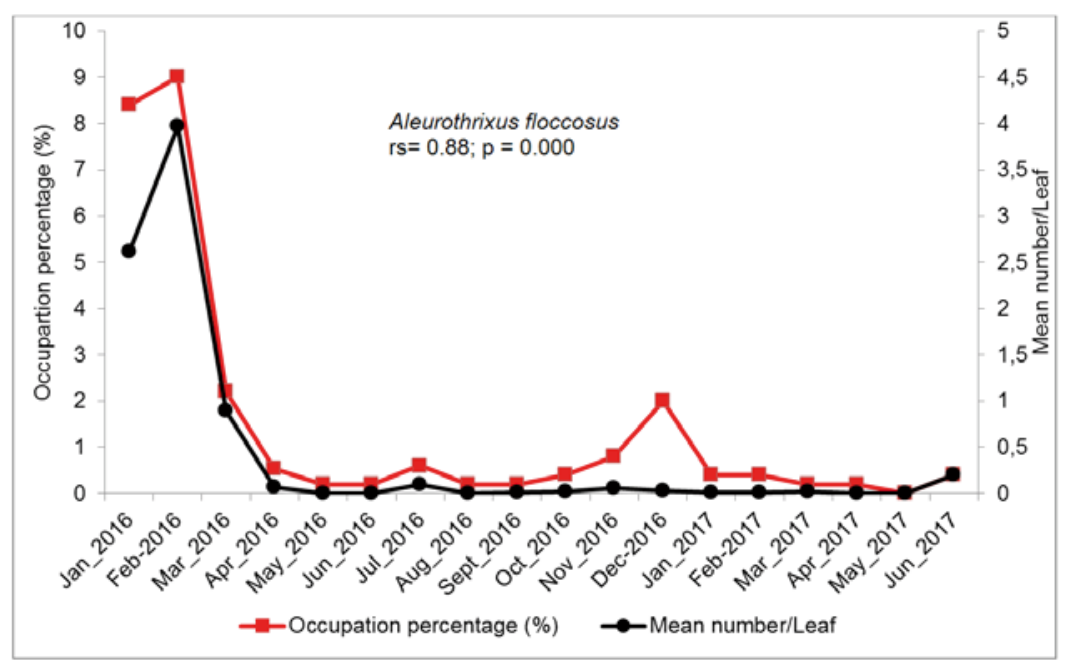

Figure 7: Temporal evolution of the mean number per leaf and the percentage of leaves occupied by Aleurothrixus floccosus (January 2016 to June 2017) 
The numbers of the other species and especially aphids were very small that we did not expect.

The species showed a variation in the period of appearance during the year. This may be due to several factors, mainly climatic conditions and the synchronization with the phenological stage of the plant.

According to several authors, the temperature has a significant effect on the seasonal dynamics of populations (Régnière et al., 2012). Others have argued that this factor is only one of many environmental factors that can influence the dynamics of arthropod populations (Roy et al., 2002; Karuppaiah \& Sujayanad, 2012).

According to Uygun and Satar (2008), five species of citrus whiteflies are known. In Algeria, four species of them have been reported, namely Paraleyrodes minei Laccarino,1990 (Benmessaoud-Boukhalfa \& Chebrou, 2014), D.citri (Boukhalfa \& Bonafonte, 1979), A.floccosus (Berkani, 1989; Mahmoudi et al., 2018), and Parabemisia myricae (Kuwana, 1927) (Berkani \& Dridi, 1992).

In our study area, we have found D.citri and A floccosus. The number of the first species was very low or absent in most cases, while for the second, its number was more important compared to the first species.

We found a relatively large number of the woolly whitefly larvae during the month of February 2016, and three other peaks, but lower, during the months of July 2016, November 2016 and June 2017, while some authors have found that heavy citrus infestations by eggs, larvae, and nymphs of A.floccosus are generally observed during the summer to the autumn period (Onillon \& Abbassi, 1973; Ulusoy et al., 2003).

We also noticed that the appearance of this insect coincided with the three sap flow of the orchard which are the spring sap flow (late February to early May), summer sap flow (July-September) and autumn sap flow (October to the end of November), and this during the year 2016, whereas during the six months of 2017, only one peak was recorded with the summer sap flow. The absence of a peak during the month of February 2017 with the spring flow is probably due to the pruning that was made at the end of December 2016.

A decrease in the number of the woolly whitefly is due to several factors, mainly the presence of the parasitoid Cales noacki Howard, 1904 (Hymenoptera, Aphelinidae) (Doumandji-Mitiche \& Doumandji, 1988; Miklasiewicz \& Walker, 1990; Mahmoudi et al., 2018). This can probably explain the very small number of this whitefly after March 2016 and until the end of sampling.

Concerning the California red scale A. aurantii, we recorded two main peaks during the sampling period; the first is during the month of March 2016 while the second is during the month of January 2017. We also noticed that another peak that began to appear with the month of
June 2017 coinciding with the development of fruit. The scale C.dictyospermi, despite its small number, showed a peak during the month of June 2016 and another during the month of June 2017, i.e. with the development of fruits and the summer sap flow.

The A. aurantii scale uncontrolled is able to destroy completely the infected orchards in two to three years(Guirrou et al., 2003). This insect can develop three generations per year in the Algerian climate; with coincidence to the tree sap flow (Belguendouz-Benkhelfa et al., 2013). This scale was found with very low number in our orchard, this may be due to the orange variety which is characterized by the presence of numerous oil glands in the leaves which can diminish the attacks (Habib et al., 1972) or probably by the presence of its parasitoids and predators in the orchard (Dao et al., 2017).The decline in California red scale in the leaf during the summer of 2016 is probably due to the migration of this insect to the fruit(Schweig \& Grunberg, 1936).

Concerning the aphids, Uygun et al. (2012) reported that there are over 25 aphid species in citrus orchards around the world, some of which are of economic importance and others likely to be present sporadically. According to the same authors, aphids infesting citrus fruits in the Mediterranean reach their maximum number in the spring, reaching another lower peak in autumn and sometimes a third of minor importance in the summer. Some aphids such as Aphis craccivora Koch, 1854, Aphis fabae Scopoli, 1763, Macrosiphum euphorbiae Thomas, 1878 and Myzus persicae Sulzer, 1776, never reach a high population level because of the activity of their natural enemies. Others, such as Aphis gossypii Glover, 1877, A. spiraecola Patch, 1914, Toxoptera aurantii (Boyer De Fonscolombe, 1841) and T. citricida Kirkaldy, 1907, are serious pests, either because they are very numerous or because they are able to transmit many viral diseases, including the citrus tristeza virus (CTV).

In Algeria, Lebbal and Laamari (2016) found in the Skikda province: Aphis gossypii, Aphis spiraecola, Macrosiphum euphorbiae, Myzus persicae and Aphis craccivora. The same authors noted that the peak of aphid infestation is observed mainly in spring and autumn. This coincides with a moderate temperature and the production of new shoots suitable for the reproduction of aphids. Many researchers have also mentioned that the peak of infestation of some citrus aphids is in spring (Saharaoui \& Hemptinne, 2009; Yoldaş et al., 2011; Mostefaoui et al., 2014).

In our study, we have found A. spiraecola and $A$. gossypii. Their number was very low or absent and this despite the absence of insecticide treatments in the study orchard. Many studies have confirmed the relationship between the damage caused by the phytophagous and the 
level of nitrogen fertilization (Baez et al., 2011; Rousselin, 2016). In our orchard, no fertilization had been done and this can have an effect on the development of young shoots that are the source of food for aphids. Most studies show an increase in the growth rate of insects with increasing temperatures (Patterson et al., 1999; Fuhrer, 2003). Other authors observed a decrease in the impact of some pests with high temperature and $\mathrm{CO}_{2}$ level in the atmosphere, such as a decrease in the number of cereal aphids in Britain with these circumstances (Newman, 2006). The existence of a national road beside our experimental orchard can cause a rise in $\mathrm{CO}_{2}$ levels, and this can probably have an effect on the presence of insect pests in the orchard, including aphids.

In terms of the cardinal directions, we noted that $A$. aurantii and C. dictyospermi prefer the center of the tree, while other species showed a preference for the sunniest directions. Cardinal directions have a significant effect on scales densities. Several authors have found that they prefer the southern direction of the canopy because of its specific micro-climate (Rodrigo \& Garcia-Marí, 1994; Campolo et al., 2014), while others have found that the scale $A$. aurantii shows a tendency toward the center of the tree (Biche et al., 2012).

Analysis of the correlation between the percentage of leaves occupied by $A$. aurantii and A. floccosus and their mean number per leaf showed a highly significant correlation with respectively ( $\mathrm{rs}=0.987, \mathrm{p}=0.000)$ and ( $r s=0.885, p=0.000$ ). This strong link confirms that as the number of both species increases on leaves, there will be migration and invasion of other healthy leaves.

\section{CONCLUSION}

The results obtained during the 18 months of monitoring, showed the presence of the following species: Aleurothrixus floccosus, Dialeurodes citri, Aphis gossypii, A.spiraecola, and eight species of scales which are Aonidiella aurantii, Lepidosaphes beckii, Parlatoria ziziphi, Chrysomphalus dictyospermi, Saissetia olea, Coccus hesperidum, C. pseudomagnoliarum and Icerya purchasi. The most abundant species was the woolly whitefly $A$. floccosus with $80.49 \%$ of the total population, followed by California red scale A. aurantii with $17.46 \%$.

The temporal monitoring of these species showed that the California red scale had a peak of development during March 2016 and the woolly whitefly also showed a main large peak during February 2016.

The correspondence analysis carried out on the cardinal directions showed a preference for installation in the canopy by the species. The two scales A. aurantii and C. dictyospermi showed a tendency towards the center of the tree, whereas the other species, their tendency was towards the sunniest parts. We also showed through our results, that if the number of the woolly whitefly and the California red scale increases in leaf, these two pests seek to occupy other healthy leaves.

It would be interesting to carry out phytochemical analyzes of the orange leaves, to highlight the relation between their components and the numbers of hemipteran species.

\section{ACKOWLEDGMENTS}

We thank Mr. Imad Fareh, responsible of plant protection at the Agricultural Services Direction of the region of Guelma (Algeria), for his help and availability in choosing orchards and contacting farmers.

\section{REFERENCES}

Affandi, A., Corpuz-Raros, L., \& Reyes, S. G. (2005). Diversity and abundance of mites in a mandarin citrus orchard in west Sumatra. Indonesian Journal of Agricultural Science, 6(2), 52-58. https://doi.org/10.21082/ijas.v6n2.2005.p52-58

Baez, I., Reitz, S. R., Funderburk, J. E., \& Olson, S. M. (2011). Variation within and between Frankliniella thrips species in host plant utilization. Journal of Insect Science, 11(41), available online: insectscience.org/11.41. https://doi. org/10.1673/031.011.0141

Belaam-Kort, I., \& Boulahia-Kheder, S. (2017). Thrips in citrus orchards, emerging pests in Tunisia. Entomologie Faustique - Faunistic Entomology, 70, 77-87.

Belguendouz-Benkhelfa, R., Biche, M., Adda, R., \& Allal-Benfekih, L. (2013). Bio-ecology of a citrus pest (Aonidiella aurantii Maskell) (Hemiptera, Diaspididae): spatiotemporal relationship with its host plants Citrus limon and C.sinensis in Algiers region. American-Eurasian Journal of Sustainable Agriculture, 7(1), 14-20.

Benhalima-Kamel, M., Rabasse, J. M., \& Ben-Hamouda, M. H. (1994). Les pucerons des agrumes et leurs ennemis en Tunisie. Tropicultura, 12(4), 145-147.

Benmessaoud-Boukhalfa, H., \& Chebrou, S. (2014). Étude preliminaire de la bio écologie de Paraleyrodes minei LACCARINO 1990 (Homoptera: Aleyrodidae : Aleyrodicinae), nouvel aleurode des citrus en Algerie. Paper presented at the AFPP-Colloque ravageurs et insectes invasifs et émergents, Montpellier.

Berkani, A. (1989). Possibilités de régulation des populations d' Aleurothrixus floccosus Mask. (Homoptera: Aleurodidae) sur agrumes par Cales noacki. (Hymenopt. Aphelinidae) en Algérie. ( Thèse Doct.Ing.), Université Aix-Marseille Fac.Sci. St.Jérôme,

Berkani, A., \& Dridi, B. (1992). Présence en Algérie de Parabemisia myricae Kuwana (Homoptera: Aleurodidae) Espèce nuisible aux-agrumes Fruits, 47, 539-540.

Biche, M., Siafa, A., Adda, R., \& Gherbi, R. (2012). Biologie de 
Aonidiella aurantii (Homoptera, Diaspididae) sur citronnier dans la région de rouiba. Lebanese Science Journal, 13(Special Issue 1), 59-64.

Boukhalfa, H., \& Bonafonte, P. (1979). Observations des populations de l'aleurode des citrus, Dialeurodes citri Ashead (Hom. Aleurodidae) dans la plaine de la Mitidja (Algérie), pendant la période hivernale et post-hivernale. Fruits, 34 , 43-52.

Campolo, O., Malacrinò, A., Laudani, F., Maione, V., Zappalà, L., \& Palmeri, V. (2014). Population Dynamics and Temperature-Dependent Development of Chrysomphalus aonidum (L.) to Aid Sustainable Pest Management Decisions. Neotropical Entomology, 43(5), 453-464. https://doi. org/10.1007/s13744-014-0226-9

Da-Silva, R. R., Teodoro, A. V., Martins, C. R., Carvalho, H. W. L. D., Silva, S. S., Farias, A. P., \& Guzzo, E. C. (2017). Seasonal variation of pest mite populations in relation to citrus scion cultivars in northeastern Brazil. Acta Agronómica, 66(2), 290-295. https://doi.org/10.15446/ acag.v66n2.55041Dao, H. T., Meats, A., Beattie, G. A. C., \& Spooner-Hart, R. (2017). Mortality on fruit in citrus orchards caused by naturally occurring enemies of red scale Aonidiella aurantii: relation to spatial distribution of patch density and season. Entomologia Experimentalis et Applicata, 162, 218-233. https://doi.org/10.1111/eea.12525

Doumandji-Mitiche, B., \& Doumandji, S. E. (1988). Note sur l'installation en mitidja de Cales noacki HOW. (Hym. Aphelinidae) ennemi naturel de l'aleurode floconneux Aleurothrixus floccosus MASK. (Homo, Aleurodidae). Annales de l'Institut National Agronomique, 12, 66-88.

Fuhrer, J. (2003). Agroecosystem responses to combinations of elevated CO2, ozone, and global climate change. Agriculture, Ecosystems and Environment, 97, 1-20. https://doi. org/10.1016/S0167-8809(03)00125-7

Garcia-Marí, F. (2009). Guía De Campo Plagas De Cítricos Y Sus Enemigos Naturales.: M.V. Phytoma-España S.L. (PhytomaEspaña).

Guirrou, Z., Kaoutari, I. E., Boumezzough, A., Chemseddine, M., \& Hilal, A. (2003). Contrôle des populations d'Aonidiella aurantii (Maskelle) en vergers d'agrumes au Maroc. Fruits, 58, 3-11. https://doi.org/10.1051/fruits:2002031

Habib, A., Salama, H. S., \& Amin, A. H. (1972). Population of Aonidiella aurantii on citrus varieties in relation to their physical and chemical characteristics. Entomologia Experimentalis et Applicata., 15, 324-328. https://doi. org/10.1111/j.1570-7458.1972.tb00216.x

Karuppaiah, V., \& Sujayanad, G. K. (2012). Impact of Climate Change on Population Dynamics of Insect Pests. World Journal of Agricultural Sciences, 8(3), 240-246.

Kheder, S. B., Jerraya, A., Jrad, F., \& Fezzani, M. (2002). Étude de la mineuse des agrumes Phyllocnistis citrella Stainton (Lep. Gracillariidae) dans la région du Cap Bon (Tunisie). Fruits, 57(1), 29-42. https://doi.org/10.1051/fruits:2002004

Kindlmann, P., \& Dixon, A. F. (2010). Modelling Population Dynamics of Aphids and Their Natural Enemies. In D. A. Kindlmann P., MICHAUD J. (Ed.), Aphid Biodiversity under Environmental Change: Springer, Dordrecht. https:// doi.org/10.1007/978-90-481-8601-3

Lebbal, S., \& Laamari, M. (2016). Population dynamics of aphids
(Aphididae) on orange (Citrus sinensis 'Thomson Navel') and mandarin (Citrus reticulata 'Blanco'). Acta agriculturae Slovenica, 107(1), 137 - 145. https://doi.org/10.14720/ aas.2016.107.1.14

Mahmoudi, A., Allal-Benfekih, L., Yigit, A., \& Goosen, M. F. A. (2018). An assessment of population fluctuations of citrus pest woolly whitefly Aleurothrixus floccosus (Maskell, 1896) (Homoptera, Aleyrodidae) and its parasitoid Cales noacki Howard, 1907 (Hymenoptera, Aphelinidae): A case study from Northwestern Algeria. Acta agriculturae Slovenica, 111(2), 407-417. https://doi.org/10.14720/ aas.2018.111.2.15

Miklasiewicz, T. J., \& Walker, G. P. (1990). Population Dynamics and Biological Control of the Woolly Whitefly (Homoptera: Aleyrodidae) on Citrus. Environmental Entomology, 19(5), 1485-1490. https://doi.org/10.1093/ee/19.5.1485

Mostefaoui, H., Allal-Benfekih, L., Djazouli, Z.-E., Petit, D., \& Saladin, G. (2014). Why the aphid Aphis spiraecola is more abundant on clementine tree than Aphis gossypii?. Comptes Rendus Biologies, 337, 123-133. https://doi.org/10.1016/j. crvi.2013.11.008

Newman, J. A. (2006). Using the output from global circulation models to predict changes in the distribution and abundance of cereal aphids in Canada : a mechanistic modeling approach. Global Change Biology., 12, 1634-1642. https:// doi.org/10.1111/j.1365-2486.2006.01192.x

Onillon, J. C., \& Abbassi, M. (1973). Notes bio-ecologiques sur l'aleurode floconneux des agrumes Aleurothrixus floccosus MASK.(Homopt., Aleurodidae) et moyens de lutte. AlAwamia, 49, 99-117.

Patterson, D. T., Westbrook, J. K., Joycr, R. J. V., Lingren, P. D., \& Rogasik, J. (1999). Weeds, insects, and diseases. Climatic change, 43, 711-727. https://doi. org/10.1023/A:1005549400875

Régnière, J., Powell, J., Bentz, B., \& Nealis, V. (2012). Effects of temperature on development, survival and reproduction of insects: Experimental design, data analysis and modeling. Journal of Insect Physiology, 58, 634-647. https://doi. org/10.1016/j.jinsphys.2012.01.010

Rodrigo, E., \& Garcia-Marí, F. (1994). Estudio de la abundancia y distribucion de algunos coccidos diaspididos de citricos. Boletin de Sanidad Vegetal Plagas, 20, 151-164.

Rousselin, A. (2016). Contribution des pratiques culturales (irrigation et fertilisation azotée) à la gestion des populations de pucerons en verger fruitier : Cas des systemes pêcher puceron vert du pêcher (Prunus persica - Myzus persicae) et pommier - puceron cendre (Malus domestica - Dysaphis plantaginea). (Doctorat en sciences), Université d'Avignon

Roy, M., Brodeur, J., \& Cloutier, C. (2002). Relationship Between Temperature and Developmental Rate of Stethorus punctillum (Coleoptera: Coccinellidae) and Its Prey Tetranychus mcdanieli (Acarina: Tetranychidae). Environmental Entomology, 31(1), 177-187. https://doi.org/10.1603/0046225X-31.1.177

Saharaoui, L., \& Hemptinne, J.-L. (2009). Dynamique des communautés des coccinelles (Coleoptera: Coccinellidae) sur agrumes et interactions avec leurs proies dans la région de Rouiba (Mitidja orientale) Algérie. Annales de la Société en- 
tomologique de France (n.s.), 45(2), 245-259. https://doi.org /10.1080/00379271.2009.10697604

Schweig, C., \& Grunberg, A. (1936). The problem of black scale (Chrysomphalus ficus Ashm.) in Palestine. Bulletin of entomological research, 27, 677-713. https://doi.org/10.1017/ S0007485300058752

Szyniszewska, A. M., \& Tatem, A. J. (2014). Global assessment of seasonal potential distribution of mediterranean fruit fly, Ceratitis capitata (Diptera: Tephritidae). PLoS One, 9(11), e111582. https://doi.org/10.1371/journal.pone.0111582

Tang, Y. Q., Lapointe, S. L., Brown, L. G., \& Hunter, W. B. (1999). Effects of Host Plant and Temperature on the Biology of Toxoptera citricida (Homoptera: Aphididae). Environmental Entomology, 28(5), 895-900. https://doi.org/10.1093/ ee/28.5.895

Ulusoy, M. R., Vatansever, G., Erkılıç, L., \& Uygun, N. (2003). Studies on Aleurothrixus floccosus (Maskell) (Homoptera, Aleyrodidae) and its parasitoid, Cales noacki Howard (Hymenoptera, Aphelinidae) in the East Mediterranean Region of Turkey. Journal of Pest Science, 76, 163-169. https://doi. org/10.1007/s10340-003-0014-5

Uygun, N., Mendoza, A. H. D., \& Baspinar, H. (2012). Aphididae In V. Vacante \& U. Gerson (Eds.), Integrated control of citrus pests in the Mediterranean region (pp. 126-136): Bentham science publishers. https://doi.org/10.2174/9781 60805294311201010126

Uygun, N., \& Satar, S. (2008). The current situation of citrus pests and their control methods in Turkey. Paper presented at the Integrated Control in Citrus Fruit Crops, Catania, Italy.

Yoldaş, Z., Güncan, A., \& Koçlu, T. (2011). Seasonal occurrence of aphids and their natural enemies in Satsuma mandarin orchards in Izmir, Turkey. Türkiye Entomoloji Dergisi, 35(1), 59-74.

Zina, V., Silva, E. B. D., Quartau, J. A., \& Franco, J. C. (2013). First report of the citrus leafhopper Penthimiola bella (Stål) (Hemiptera, Cicadellidae) in Europe. Phytoparasitica, 41, 521-527. https://doi.org/10.1007/s12600-013-0312-2 